\title{
Graduate Students' Perceptions on their Self-Efficacy in Writing Academic Papers
}

\author{
Kristian Florensio Wijaya \\ kristianwijaya500@gmail.com \\ Concilianus Laos Mbato \\ cons@usd.ac.id
}

Sanata Dharma University, Yogyakarta

\begin{abstract}
It is notable to note here that self-efficacy needs to be ingrained strongly within graduate students to show a higher enthusiasm, efforts, and persistence in accomplishing various demanding academic writing projects. Tangibly, there are still many graduate students who lack motivation and confidence when doing academic writings. As a result, their attitudes toward writing turn into negative actions crippling their self-efficacy. This study aimed to investigate graduate students' perceived self-efficacy in academic writings. One research problem was formulated in this study namely, how do English Education Master Students maintain their self-efficacy to accomplish their academic writings? This study employed a mixed-method harnessing classroom survey and interview questions to gather data from English Education Master Students engaging in academic writings, Sanata Dharma University, Yogyakarta. Findings from this study revealed that graduate students are able to produce more qualified academic writing products when they are motivated continuously by their lecturer.
\end{abstract}

Keywords: self-efficacy, perceptions, academic writings, graduate students, mixed method

\section{INTRODUCTION}

Writing is one of the most challenging EFL competencies which need to be mastered fully by EFL learners since they will be able to broaden their perspectives through qualified writing discourses in the forms of good arguments, narratives, and opinions. Erkan and Saban (2011) state that writing is an essential EFL skill since the learners are trained harder to depict all of their ideas in the forms of academic sentences to look more scholarly. (Smith, Cheville, \& Hillocks, 2006) argue that learners will not be able to possess critical thinking skills if they are not rehearsed to share their thoughts through writing. Concerning this conception, EFL learners must develop their writing competencies through academic writing consistently for they will be handicapped as scholar academicians or unqualified graduates after accomplishing their studies in colleges. However, to make EFL learners to be more qualified academic writers is not an easy matter since there is a huge gap between the educators' and learners' expectations when commencing academic writing processes and learners frequently encounter serious impediments while attempting to accomplish their academic writing projects such as lack of motivation, a tendency to do a procrastination, writing anxiety, and unclear objectives in their writing dynamics. Pajares (2003) asserts that EFL learners often do not know their educators' expectations on their writing products, and finally this confusion leads them to be learned helplessness in writing. 
Moving forward to a more in-depth topic on academic writing, all of these common issues do not only occur in global but also Indonesia context. In Indonesia, most EFL learners particularly beginner learners frequently discover that writing is a difficult subject for them since they do not possess strong beliefs in themselves that they are capable of accomplishing their writing projects amid unpredictable obstacles. Setyowati (2016) reported that there is a huge number of EFL Indonesian learners who have transformed themselves become learned helplessness since they always perceive writing is a laborious work for them to be completed. In a similar vein, graduate students also encounter similar obstructions in doing academic writing as other EFL learners have already experienced before because of the flourishing growth of writing anxiety. Before going deeper on this term in the next section, it is worthwhile to be noticed that graduate students also demand intensive writing programs to make them more proficient in academic writing. Unfortunately, most educators have already assumed that graduate students do not need to be advised and supervised intensely as undergraduate students in their academic writings since they have been expertise in the writing processes. Mullen (2006) states most of the academicians perceive graduate students have already possessed qualified writing skills and they do not have to be guided extensively. Due to this fact, this study is undertaken to yield renewable perspectives for EFL academicians and educators that graduate students extremely require extensive supervision when attempting to accomplish their academic writings. Therefore, this study also strived for digging up graduate students' perceptions focusing on their self-efficacy in academic writings to identify the consecutive processes they have done when finishing their writing projects, which are eventually beneficial to be utilized for future academic writing processes to improve their quality of writings. Furthermore, a limited study on graduate students' perceptions of academic writing is another rationale why this study needs to be conducted. (Fergie et al. 2011 \& Lindsay, 2015) reported that most of the studies on academic writings put their sharp focus on undergraduate thesis rather than graduate students' writings.

It is worth restating here that there are seven current studies of academic writing conducted around the globe. The first study was conducted by (Mbato \& Cendra, 2019). They discovered that self-regulated EFL learners can accomplish their undergraduate thesis writing since they have known how to seek help from others and maintain their learning motivation continuously. The second interesting study was held by (Samsidar, Jabu, \& Basri, 2019). They found that Youtube video is helpful to enhance EFL secondary students' writing skills in terms of the dictions, words, and structure of the target language. (Mutiamiftah, Atmowardoyo, \& Jabu, 2018) discovered that email has helped graduate students to perform better writing performances due to its simplicity, feasibility, and comfort. Furthermore, (Mustafa, Rashid, Atmowardoyo, \& Dollah, 2015) founded that EFL learners who possess positive attitudes toward the English language will be able to be more persistent and motivated while engaging in the second language learning processes. Moreover, (Kamariah, Husain, Atmowardoyo, \& Salija, 2018) discovered that indepth writing materials design comprising of discussions, pre-writing, whilst writing, and post-writing activities will develop EFL learners' writing competencies. (Aridah, Atmowardoyo, \& Salija, 2017) also found that clearer and appropriate writing instructions together with feedback should be provided for EFL learners to enable them to fulfill teachers' expectations successfully. (Akil, Hamra, Atmowardoyo, \& Tjalla, 2018) suggested writing materials should be equivalent to EFL learners' writing preferences, needs, proficiency, and socio-cultural backgrounds to foster their motivation in second language writing learning dynamics. The previous researchers agreed that EFL learners need to maintain their writing volitions continuously to show significant improvements in particular writing projects. However, none of the studies above has delved more profoundly about specific steps graduate students undertake to maintain their self-efficacy in writing academic papers. To fill this gap, this study was conducted specifically attempting to investigate common strategies graduate students usually do to preserve their self-efficacy in academic writings continuously. One research problem was formulated in this study namely: How do English Education Master Students maintain their self-efficacy to accomplish their academic writings? 


\section{LITERATURE OF REVIEW}

As mentioned previously, this chapter will cast more focus on four factors determining the successful academic writing completions done by English Education Master Students namely writing anxiety, social cognitive theory, perceived self-efficacy, and emotional intelligence. All of these four terms are in accord with self-efficacy which is believed to prompt students' internal motivation to accomplish their academic writing projects amid hardships. Further explanations of these four terms can be seen as follows.

\section{Writing Anxiety}

This term refers to negative writers' attitude when confronting with workloads in writing tasks. Normally, they will experience stressful situations, restless, and writing blocks. (Boice \& Johnson, 1984) argue if the writers establish a higher degree of anxiety within themselves, they will not be able to be more productive in generating ideas since they worry excessively about their abilities to accomplish the tasks. Moreover, writing anxiety is also dangerous for the continuity of EFL writers' writing products since their quality of works will be poor which will be resulted in unsatisfying academic achievements. (Daly \& Miller, 1975) reported that undergraduate students, who possessed a higher level of writing anxiety, have produced the lower quality of writing products rather than those who ingrained a minimum degree of writing anxiety. (Martinez, Kock, \& Cass, 2011) believe that writing anxiety will lead the learners to attain poor academic achievements since unqualified writing products are generated. Another dimension of writing anxiety can also be discerned when the learners prone to procrastinate their works, do not possess a higher level of self-confidence and ingrain negative feelings toward every stuff related to writing. (Riffe \& Stacks, 1992) state that writing anxiety depends on the tasks' level of difficulty given by the teachers and learning conditions which can promote negative feelings and insecurity for the learners. Besides, some other factors also play a major contribution to the strong establishment of writing anxiety such as traumatic experiences undergone by the learners in prior writing experiences, teachers' negative judgments on students' writing products, and unsupportive writing learning environments created by the teachers or peers. (Foroutan \& Noordin, 2012) argue that writing anxiety is induced by some specific writing conditions in which the learners involved. For instance, the learners feel afraid of making some grammatical mistakes when the teachers ask them to write academic essay writing.

\section{Social Cognitive Theory}

To minimize a higher level of writing anxiety in academic writing processes, the teachers should be able to create a more holistic learning environment in which all of the learners' voices, efforts, and persistence are highly valued. This conception deals mostly with social cognitive theory. The social cognitive theory emphasizes more heavily on meaningful human interactions during engaging in the learning processes. In other words, mutual interactions should be persisted constantly to achieve full success in learning. Bandura (1986) asserts that supportive learning environments will allow the learners to experience a higher degree of enjoyment in their learning dynamics since all of the environmental factors positively support their learning. Schunk (1995) states that a great level of self-efficacy will lead the learners to obtain more satisfying academic achievements since they have been able to determine their learning objectives and put more efforts to attain these goals in the presence of adversity. Therefore, the teachers should be able to navigate their learners to pursue their learning objectives determined at the onset of their learning to foster their levels of self-efficacy into the utmost. In other words, the learners will proceed in another challenging learning journey if they found themselves capable of accomplishing various challenging matters before. These basic conceptions of self-efficacy are corresponding with a study conducted by (Hashemnejad, Zoghi, \& Amini, 2014). They discovered that there is a strong correlation between EFL learners' self-efficacy and their writing performances. As argued before, the teachers can sustain learners' self-efficacy in writing learning processes by providing more meaningful 
feedback useful to navigate their future learning journeys. This action needs to be taken by the teachers unless disruptive behaviors of lower self-efficacious learners will devastate the whole learning processes. On the other hand, conducive learning circumstances can also be created successfully as a result of continuous investment of teachers' patience and passion in nurturing their learners' self-efficacy. (Federici \& Skaalvik, 2012) discovered EFL learners will be more competent and self-regulated writers if they have increased their self-efficacy levels gradually.

\section{Perceived Self-Efficacy}

Bandura (1993) states that perceived self-efficacy deals with the learners' beliefs that they have great capabilities to attain great success in their learning through persistent efforts and long-lasting motivation. There are four sources of self-efficacy proposed by Bandura (1977) namely mastery experience, vicarious experience, verbal persuasion, and psychological states. As mentioned in previous literature, the learners will continue their likelihood of success in their future learning of they have already experienced satisfying learning progress and outcomes in their prior learning journeys. Furthermore, the learners will also be able to accomplish various challenging learning tasks if they are willing to imitate their learning companions' success through learning dynamics. More importantly, internal supports are proved as inadequate to corroborate learners' self-efficacy levels consistently since they also demand two other external sources of self-efficacy namely verbal persuasion and psychological arousal. To reiterate, the learners should always be motivated and guided patiently by the teachers that they have excellent abilities to carry out many kinds of difficult tasks. This kind of action will lead the learners to stay on their right tracks in learning since they feel accepted, appreciated, and motivated by their teachers which results in the successful creation of conducive learning environments. All of these four sources of self-efficacy need to be integrated into academic writing processes since the learners will show more persistent efforts to accomplish their writing projects amid difficult situations and restricted time constraints. In line with prior concepts of self-efficacy, (Martinez, Kock, \& Cass, 2011) believe that the learners will not give up easily in their writing processes if continuous supports and conducive learning circumstances are embedded in their lives as writers. When the teachers have been successful in promoting all of these four main sources of self-efficacy in students' writing processes, the learners will eventually be able to generate more qualified writing products since they can develop their critical thinking skills smoothly with a consistent supports given by their teachers in terms of physiological and emotional assistance. (Bulut, 2017) states that EFL learners' attitudes and self-efficacy levels will heavily influence their enjoyment and performances in writing.

\section{Emotional Intelligence}

This ultimate term also determines the successful growth of EFL learners' self-efficacy in academic writing since it will lead the learners to focus on attaining their writing learning objectives successfully by regulating their emotions, feelings, and mind during the completion of writing products. (Salovey \& Mayer, 1990) state that emotional intelligence is people's ability to manage their emotions, feelings, and thinking to be able to utilize all of these internal factors to lead them to take precise behaviors for the successful completion of their tasks. For this main reason, emotional intelligence is extremely pivotal to be harnessed in the learners' self-efficacy development to predict their academic performances and achievements in the future. (MacCann, Lievens, Libbrecht, \& Roberts, 2016) believe emotional intelligence is an appropriate measurement for the learners' future academic performances and achievements. In correlation to writing, (Shao, Yu, \& Ji, 2013) also discovered that there is a tight-knit relationship amid Chinese EFL learners' emotional intelligence, writing performances, and writing achievements in particular English classes proposed by some colleges in China. 


\section{METHOD}

To obtain a clearer understanding and stronger evidence regarding one particular phenomenon, the researchers utilized a mixed-method in this study. (Creswell, Clark, \& Garrett, 2003) state a mixed method is a type of study integrating both qualitative and quantitative approaches to provide a more profound understanding of one phenomenon. Two research instruments were also utilized in this study to reach that previous research objective namely Likert-scale questionnaire and interview protocols. The participants of this study will be 15 graduate Students of English Education Department at Sanata Dharma University. The researchers chose them as the research participants of this study to obtain their perspectives on self-efficacy upon completing their academic writing projects starting from the first until this even semester. For the data gathering techniques, the researchers are going to distribute the Likertscale questionnaire consisting of 10 statements about English Education Master Students' perceptions of their self-efficacy in writing academic papers. In the next step, the researchers planned to conduct intensive interview sections with 2 selected interviewees in focus group discussion asking about their steps while maintaining their self-efficacy to complete their academic writing projects. Concerning a mixed-method utilized in this study, the researcher divided the degree of agreements into "strongly agree", "agree", "neutral", "disagree", and "strongly disagree". Afterward, the researchers planned to cluster all of the obtained data in descriptive statistics and exhibit the total responses of each research participant in the form of percentages. Each percentage will be calculated by utilizing this formula:

$$
\sum \mathrm{x} / \sum \text { n. } 100 \%
$$

\section{RESULTS AND DISCUSSIONS}

This chapter is enacted to summarize all of the findings obtained through the Likert-scale questionnaire and interview activities regarding graduate students' perceptions of their self-efficacy in academic writings. The first finding deals with the influences of external and internal factors sustaining graduate students' self-efficacy while engaging in academic writing activities. The second finding emphasizes more on the importance of stronger levels of self-efficacy to lead graduate students to obtain their academic writings' success. Each of the findings will be presented in the table in the forms of percentages and accompanied by some essential excerpts of the interview results, relevant prior findings generated by previous studies, and related theories to yield better enlightenment for in-depth discussion throughout this section. All of the findings and explanations will be seen as follows.

Table 4.1 Questionnaire Results of some external and internal supports which can sustain graduate students' self-efficacy in academic writings

\begin{tabular}{|c|c|c|c|c|c|c|}
\hline No & Statements & $\begin{array}{l}\text { Strongly } \\
\text { Disagree }\end{array}$ & Disagree & Neutral & Agree & $\begin{array}{c}\text { Strongly } \\
\text { Agree }\end{array}$ \\
\hline 1. & $\begin{array}{l}\text { As English Education Master } \\
\text { Students, I believe that academic } \\
\text { writing skills are essential to be } \\
\text { mastered to make me look more } \\
\text { scholarly }\end{array}$ & $\begin{array}{c}1 \\
7,14 \%\end{array}$ & - & - & $\begin{array}{c}5 \\
35,7 \%\end{array}$ & $\begin{array}{c}8 \\
57,1 \%\end{array}$ \\
\hline 2. & $\begin{array}{l}\text { I can overcome my writing anxiety } \\
\text { since I believe that I have enough } \\
\text { capabilities to produce qualified } \\
\text { academic writing products }\end{array}$ & - & $\begin{array}{c}1 \\
7,14 \%\end{array}$ & $\begin{array}{c}4 \\
28,5 \%\end{array}$ & $\begin{array}{c}8 \\
57,1 \%\end{array}$ & $\begin{array}{c}1 \\
7,14 \%\end{array}$ \\
\hline
\end{tabular}




\begin{tabular}{|c|c|c|c|c|c|c|}
\hline 3. & $\begin{array}{l}\text { By observing my colleagues' } \\
\text { academic writing success, I have } \\
\text { ingrained more robust desire to } \\
\text { improve my academic writing skills } \\
\text { as well }\end{array}$ & - & $\begin{array}{c}1 \\
7,14 \%\end{array}$ & - & $\begin{array}{c}11 \\
78,5 \%\end{array}$ & $\begin{array}{c}2 \\
14 \%\end{array}$ \\
\hline 4. & $\begin{array}{l}\text { When my academic writing } \\
\text { products are appraised and accepted } \\
\text { by my academic advisors, my } \\
\text { likelihood to succeed in writing } \\
\text { academically will be higher }\end{array}$ & - & - & $\begin{array}{c}1 \\
7,14 \%\end{array}$ & $\begin{array}{c}7 \\
50 \%\end{array}$ & $\begin{array}{c}6 \\
42,8 \%\end{array}$ \\
\hline 5. & $\begin{array}{l}\text { I feel more confident to accomplish } \\
\text { my academic writing projects if my } \\
\text { academic advisors and colleagues } \\
\text { always address continuous } \\
\text { encouragement to me }\end{array}$ & $\begin{array}{c}1 \\
7,14 \%\end{array}$ & - & - & $\begin{array}{c}7 \\
50 \%\end{array}$ & $\begin{array}{c}6 \\
42,8 \%\end{array}$ \\
\hline
\end{tabular}

Table 4.1 above exhibited the results of the first five statements to discover some external and internal factors which can sustain graduate students' self-efficacy in academic writings. The first statement showed that 8 graduate students $(57,1 \%)$ chose "strongly agree" and 5 graduate students $(35,7 \%)$ chose "agree". From this finding, we can conclude that most of the graduate students have viewed academic writing activities as indispensable for their academic life as academicians to make them look more scholarly. This finding is in accord with Nunan's theory (2015) about writing. He argued that academic writing is an effective medium of communication linked to human beings to make them more open-minded. In the second statement, there was 1 graduate student $(7,14 \%)$ who chose "strongly agree" and 8 students $(57,1 \%)$ who chose "agree". From this finding, it can be inferred that most of the graduate students can exert more control over their writing anxiety since they have put strong beliefs in their writing capabilities. This finding is aligned with previous research findings discovered by Bulut (2017). He found that writing beliefs and attitudes will promote significant impacts to the writing products produced by EFL learners. In the third statement, there were 2 graduate students (14\%) who chose "strongly agree" and 11 graduate students $(78,5 \%)$ who chose "agree". Regarding this finding, it can be argued that most of the graduate students can show some significant performances in academic writings since they are willing to imitate other learning counterparts' effective writing strategies to be qualified academic writers. This finding is in line with prior finding discovered by (Moran \& McMaster, 2009). They found that verbal persuasion will be beneficial and meaningful for future writing learning dynamics since language teachers can devise renewable learning strategies compatible with EFL learners writing proficiency which leads them to instill a higher level of self-efficacy. The fourth statement showed that 6 graduate students $(42,8 \%)$ chose "strongly agree" and 7 graduate students $(50 \%)$ chose "agree". This finding indicates most graduate students are capable of repeating similar academic writing success if they have been exposed to this kind of positive learning nuance in their past time. This fourth finding is corresponding with the previous finding discovered by (Mbato \& Cendra, 2019). They found that undergraduate students' motivation in thesis writing will be nourished consistently if meaningful and continuous supports are always given by their thesis advisors. The last finding is closely correlated with the fourth finding for there were 6 graduate students $(42,8 \%)$ chose "strongly agree" and 7 graduate students $(50 \%)$ chose "agree". From this last finding, it can be argued that most of the graduate students have shown more persistent efforts, greater motivation, and confidence when completing their challenging academic writing projects since continuous moral supports are always addressed by their lecturer along with learning companions. This ultimate finding is akin to the theory of learning motivation proposed by (Brown et al., 2011). They stated that an excessive level of writing anxiety needs to be reduced before engaging EFL learners to produce their writing products unless they will tend to withdraw themselves from particular writing activities. All of these aforementioned first five findings will be 
corroborated with 2 particular excerpts obtained from the interview. The first and second interviewees stated that:

(1) I realize that I only have limited time to finish a demanding project and I also have another job besides the campus life. Therefore, I always manage my time very well, time management is really important for me.

(2) I need to manage my time well since there are many academic writings to be accomplished based on the courses I have taken.

The excerpt number 1 showed that this graduate student was able to be more self-regulated learners since she had to deal with her job besides her academic stuff. The excerpt number 2 revealed that this graduate student had more perseverance and long-lasting efforts to accomplish his academic writing projects not only to produce qualified academic writing products but also to pass the courses with satisfying results. These two important findings are closely interlinked with two theories of selfregulation proposed by (Zimmerman, Bonner, \& Kovach, 1996) and (Mbato, 2013). The first experts stated that high self-regulated learners will be able to be more responsible for their learning. The second experts also asserted that intended learning objectives will be attained by the learners after they are able to utilize their learning strengths and weaknesses.

Table 4.2 Questionnaire Results of Impacts Promoted by Self-Efficacy in Academic Writings

\begin{tabular}{|c|c|c|c|c|c|c|}
\hline No & Statements & $\begin{array}{l}\text { Strongly } \\
\text { Disagree }\end{array}$ & Disagree & Neutral & Agree & $\begin{array}{c}\text { Strongly } \\
\text { Agree }\end{array}$ \\
\hline 6. & $\begin{array}{l}\text { When I attribute academic writing } \\
\text { projects as intriguing and } \\
\text { interesting learning activities, I } \\
\text { believe that I will be able to } \\
\text { generate good writing products }\end{array}$ & - & - & - & $\begin{array}{c}11 \\
78,5 \%\end{array}$ & $\begin{array}{c}3 \\
21,4 \%\end{array}$ \\
\hline 7. & $\begin{array}{l}\text { When I can establish a higher } \\
\text { degree of self-efficacy in academic } \\
\text { writings, I will discover many kinds } \\
\text { of strategies to accomplish my } \\
\text { writing tasks amid challenging } \\
\text { writing situations }\end{array}$ & $\begin{array}{c}1 \\
7,14 \%\end{array}$ & - & - & $\begin{array}{c}9 \\
64,2 \%\end{array}$ & $\begin{array}{c}4 \\
28,5 \%\end{array}$ \\
\hline 8. & $\begin{array}{l}\text { I am confident that I will be able to } \\
\text { yield more qualified academic } \\
\text { writings if I am persisting in } \\
\text { obtaining my objectives through } \\
\text { my writing projects }\end{array}$ & $\begin{array}{c}1 \\
7,14 \%\end{array}$ & - & $\begin{array}{c}1 \\
7,14 \%\end{array}$ & $\begin{array}{c}11 \\
78,5 \%\end{array}$ & $\begin{array}{c}1 \\
7,14 \%\end{array}$ \\
\hline 9. & $\begin{array}{l}\text { I can stay calm although there are } \\
\text { many writing impediments during } \\
\text { my academic writing journeys since } \\
\text { I have dedicated all of my efforts, } \\
\text { commitment, and perseverance to } \\
\text { finish my writings }\end{array}$ & - & $\begin{array}{c}1 \\
7,14 \%\end{array}$ & $\begin{array}{c}6 \\
42,8 \%\end{array}$ & $\begin{array}{c}7 \\
50 \%\end{array}$ & - \\
\hline
\end{tabular}




\begin{tabular}{|l|l|c|c|c|c|c|}
\hline 10. & $\begin{array}{l}\text { I feel certain that academic writing } \\
\text { activities will be more feasible and } \\
\text { enjoyable if my academic advisors } \\
\text { have also dedicated all of their } \\
\text { perseverance, commitment, and } \\
\text { efforts in guiding me during the } \\
\text { writing processes }\end{array}$ & $7,14 \%$ & - & - & 7 & $60 \%$ \\
\hline
\end{tabular}

Table 4.2 represented the results of the second five statements in order to discover tangible impacts promoted by self-efficacy in academic writings. The sixth statement showed that 3 graduate students $(21,4 \%)$ chose "strongly agree" and 11 graduate students $(78,5 \%)$ chose "agree". Based on this finding, it can be inferred that most of the graduate students are able to show positive attitudes and attributions for academic writing activities since they view these activities as dynamics and challenging. This finding shared a similar relationship with the previous finding discovered by (Gupta \& Woldemariam, 2011). They found that highly-motivated EFL learners tend to employ many kinds of strategies in their writings since they have possessed a higher degree of enjoyment and a positive attitude toward writing subjects. In the seventh statement, there were 4 graduate students $(28,5 \%)$ who chose "strongly agree" and 9 graduate students $(64,2 \%)$ who chose "agree". Regarding this seventh finding, it can be concluded that most of the graduate students are able to gain more powerful controls over their academic writing processes since they have ingrained robust self-efficacy within themselves. This finding is mutually interconnected with the prior finding discovered by (Troia, Shankland \& Wolbers, 2012). They found that high self-efficacious learners tend to be tougher in encountering many kinds of unpredictable obstacles and challenges in their writing processes since they possess stronger writing volitions and plenty of writing strategies in their learning accounts. In the eighth finding, there was one graduate student $(7,14 \%)$ chose "strongly agree" and 11 graduate students $(78,5 \%)$ chose "agree". In conformance with this finding, it can be argued that most of the graduate students are able to be more persistent in accomplishing their academic writing projects since they adhere continuously to their learning objectives set by them before. This finding is closely related to the prior finding discovered by Tran (2007). The researcher discovered that EFL learners will show more persistent efforts and longlasting learning spirit in their writing dynamics when the teachers are willing to nurture their external and internal motivation mutually integrated with learners' goals in writing. The ninth statement showed that there were 7 graduate students $(50 \%)$ chose "agree". Regarding this finding, it can be concluded that most of the graduate students are optimistic to accomplish their academic writing projects successfully since they have dedicated all of their efforts, commitment, and motivation in these challenging activities. This finding is corresponding with the previous finding discovered by (Troia, Harbaugh, Shankland, Wolbers, \& Lawrence, 2013). They found that EFL learners' degree of motivational beliefs and specific interests in writing tasks, outcomes, and expectancy of writing success will influence their writing engagement and quality of their writing products. In the last finding, there were 6 graduate students $(42,8 \%)$ chose "strongly agree" and 7 graduate students $(50 \%)$ chose "agree". In relation to this finding, it can be concluded that most of the graduate students are able to view academic writing processes as enjoyable, intriguing, and rewarding learning activities for them to engage since their lecturer shows profound caring, attentiveness, and commitment to guide them to accomplish their writing projects. This ultimate finding is closely correlated with the previous finding discovered by (Maarof, Yamat, \& Li, 2011). They discovered that teacher's roles as instructors will empower EFL learners' writing processes since corrective, meaningful, and constructive feedback will lead learners for the betterment of their future learning dynamics. All of these previous explanations are in line with two selected excerpts of interviews provided below. The first and second interviewees stated that:

(1) I always nurture my strong commitment in academic writing by saying to myself that I am able to accomplish it on time. Also, supports given by other friends will have meaningful impacts for me. 
(2) External factors such as the influences of other friends or learning peers that support me continuously to accomplish academic writings successfully.

The excerpt number 1 showed that this graduate student always nurtures her internal motivation continuously while accomplishing her academic writing projects. In a similar vein, she also acknowledged that continuous moral supports and encouragement given by other learning peers also keep her to stay on the right track in academic writing. Further, excerpt number 2 also exhibited that this graduate student was able to accomplish his academic writing projects as long as other learning companions provide meaningful supports for him. These two pivotal findings are closely interlinked with two theories proposed by (Dillenbourg, 2002) and (Stahl, 2005). The first expert stated that positive social interdependence among learners in collaborative learning groups will enable them to assist each other when they encounter serious impediments in learning. Furthermore, the second expert also asserted that collaborative learning groups will empower whole learners' learning processes since verbal persuasions always spark in the midst of obstacles and challenges.

\section{CONCLUSIONS, IMPLICATIONS, AND SUGGESTIONS}

Given this complex picture, it is essential to restate here that academic writing skills are extremely crucial and should be mastered fully by EFL learners, particularly graduate students. To attain this main objective is not an overnight processes for academic writing advisors need to provide continuous moral supports for their learners, create more supportive learning environments, design writing materials relevant with learners' proficiency, and understand their learners' writing needs profoundly. All of these actions need to be coupled with internal learning motivation established by the learners, especially when they have viewed academic writing as positive, rewarding, and meaningful activities determining their future careers as future academicians after accomplishing their graduate programs. Needless to say, to show significant and satisfying performances in academic writing, the teachers and learners need to be able to cooperate well to select exact writing preferences, fulfill academic writings' requirements, and produce more qualified writing products. All in all, all of these objectives can be attained successfully only if the learners have established stronger volitions in academic writings intertwined with powerful supports given by their academic writing advisors. In accord with these closing remarks, there are 2 major suggestions addressed for the future researchers who are going to conduct similar study in this area. First, future researchers need to delve more profoundly about the correlations between EFL learners' attitudes, beliefs, and self-efficacy in academic writings to yield richer data for EFL teachers who teach academic writing in their classes. Lastly, since this study is only done with a small number of participants, it will be more useful for future researchers to conduct their studies on the role of self-efficacy in graduate students' academic writings by involving more research participants to generate more powerful findings for EFL teachers to implement suitable academic writing activities and strategies in which learners can nourish their self-efficacy continually.

\section{REFERENCES}

Akil, M., Hamra, A., Atmowardoyo, H., \& Tjalla, M. (2018). Evaluating a New Writing Material: Students' Perception towards the Use of a Teacher-made Coursebook. Journal of Language Teaching and Research, 9(3), 525-533.

Aridah, A., Atmowardoyo, H., \& Salija, K. (2017). Teacher Practices and Students' Preferences for Written Corrective Feedback and Their Implications on Writing Instruction. International Journal Of 
English Lingusitics, 7(1), 112-125. Bandura, A. (1977). Self-efficacy: toward a unifying theory of behavioral change. Psychological review, 84(2), 191.

Bandura, A. (1986). Fearful expectations and avoidant actions as coeffects of perceived self-inefficacy.

Bandura, A. (1993). Perceived self-efficacy in cognitive development and functioning. Educational psychologist, 28(2), 117-148.

Boice, R., \& Johnson, K. (1984). Perception and practice of writing for publication by faculty at a doctoral-granting university. Research in Higher Education, 21(1), 33-43.

Bulut, P. (2017). The effect of primary school students' writing attitudes and writing self-efficacy beliefs on their summary writing achievement. International Electronic Journal of Elementary Education, 10(2), 281-285.

Creswell, J. W., Clark, V. P., \& Garrett, A. L. (2003). Advanced mixed methods research. Handbook of mixed methods in social and behavioural research. Thousand Oaks, CA: Sage, 209-240.

Daly, J. A., \& Miller, M. D. (1975). The empirical development of an instrument to measure writing apprehension. Research in the Teaching of English, 9(3), 242-249.

Dillenbourg, P. (2002). Over-scripting CSCL: The risks of blending collaborative learning with instructional design.

Erkan, D. Y., \& Saban, A. İ. (2011). Writing performance relative to writing apprehension, self-efficacy in writing, and attitudes towards writing: A correlational study in Turkish tertiary-level EFL. The Asian EFL Journal Quarterly March 2011 Volume 13, Issue, 13(1).

Federici, R. A., \& Skaalvik, E. M. (2012). Principal self-efficacy: Relations with burnout, job satisfaction and motivation to quit. Social Psychology of Education, 15(3), 295-320.

Fergie, G., Beeke, S., McKenna, C., \& Creme, P. (2011). " It's a Lonely Walk": Supporting Postgraduate Researchers through Writing. International journal of teaching and learning in higher education, 23(2), 236-245.

Foroutan, M., \& Noordin, N. (2012). Effect of dialogue journal writing through the use of conventional tools and e-mail on writing anxiety in the ESL context. English Language Teaching, 5(1), 10-19.

Gupta, D., \& Woldemariam, G. S. (2011). The influence of motivation and attitude on writing strategy use of undergraduate EFL students: Quantitative and qualitative perspectives. Asian EFL Journal, 13(2), 34-89.

Hashemnejad, F., Zoghi, M., \& Amini, D. (2014). The Relationship between Self-efficacy and Writing Performance across Genders. Theory \& Practice in Language Studies, 4(5).

Jerusalem, M., \& Schwarzer, R. (1995). Generalized self-efficacy scale. Measures in health psychology: A user's portfolio. Causal and control beliefs, 35-37.

Kamariah, A., Husain, D., Atmowardoyo, H., \& Salija, K. (2018). Developing authentic-based instructional materials for writing skill. Journal of Language Teaching and Research, 9(3), 591-599.

Lindsay, S. (2015). What works for doctoral students in completing their thesis?. Teaching in Higher Education, 20(2),

183-196. 
Maarof, N., Yamat, H., \& Li, K. L. (2011). Role of teacher, peer and teacher-peer feedback in enhancing ESL students' writing. World Applied Sciences Journal, 15(Innovation and Pedagogy for Lifelong Learning), 35-29.

MacCann, C., Lievens, F., Libbrecht, N., \& Roberts, R. D. (2016). Differences between multimedia and text-based assessments of emotion management: An exploration with the multimedia emotion management assessment (MEMA). Cognition and Emotion, 30(7), 1317-1331.

Martinez, C. T., Kock, N., \& Cass, J. (2011). Pain and pleasure in short essay writing: Factors predicting university students' writing anxiety and writing self-efficacy. Journal of Adolescent \& Adult Literacy, 54(5), 351-360.

Mbato, C. L. (2013). Facilitating EFL learners' self-regulation in reading: Implementing a metacognitive approach in an Indonesian higher education context.

Mbato, C. L., \& Cendra, A. (2019). Efl undergraduate students' self-regulation in thesis writing: helpseeking and motivation-regulation. JELE (Journal of English Language and Education), 5(1), 66-82.

Mullen, C. A. (2006). Best writing practices for graduate students: Reducing the discomfort of the blank screen. Kappa Delta Pi Record, 43(1), 30-35.

Mustafa, H. H., Rashid, M. A., Atmowardoyo, H., \& Dollah, S. (2015). Students' attitudinal factors in learning English as a foreign language. Journal of Language Teaching and Research, 6(6), 11871194.

Mutiamiftah, M., Atmowardoyo, H., \& Jabu, B. (2018). Emailing in English Writing: a Case Study Towards Students in Two Classes at SMA Negeri 1 Sinjai. ELT WORLDWIDE, 5(2), 83-96.

Nunan, D. (2015). Teaching English to speakers of other languages: An introduction. Routledge.

Pajares, F. (2003). Self-efficacy beliefs, motivation, and achievement in writing: A review of the literature. Reading \&Writing Quarterly, 19(2), 139-158.

Riffe, D., \& Stacks, D. W. (1992). Student characteristics and writing apprehension. The Journalism Educator, 47(2), 39-49.

Salovey, P., \& Mayer, J. D. (1990). Emotional intelligence. Imagination, cognition and personality, 9(3), $185-211$.

Samsidar, S., Jabu, B., \& Basri, M. (2019). Enhancing Students' Ability to Write Procedure Text through YouTube Video (Doctoral dissertation, Universitas Negeri Makassar).

Schunk, D. H. (1995). Self-efficacy, motivation, and performance. Journal of applied sport psychology, 7(2), 112-137.

Setyowati, L. (2016). Analyzing the students' ability in writing opinion essay using flash fiction. Journal of English Language Teaching and Linguistics, 1(1), 79-92.

Shao, K., Yu, W., \& Ji, Z. (2013). The relationship between EFL students' emotional intelligence and writing achievement. Innovation in language learning and teaching, 7(2), 107-124.

Smith, M., Cheville, J., \& Hillocks, G. (2006). I guess I'd better watch my English. Handbook of writing research, 
Stahl, G. (2005). Group cognition in computer-assisted collaborative learning. Journal of Computer Assisted Learning, 21(2), 79-90.

Tran, L. T. (2007). Learners' motivation and identity in the Vietnamese EFL writing classroom. English Teaching: Practice and Critique, 6(1), 151-163.

Troia, G. A., Harbaugh, A. G., Shankland, R. K., Wolbers, K. A., \& Lawrence, A. M. (2013). Relationships between writing motivation, writing activity, and writing performance: Effects of grade, sex, and ability. Reading and Writing, 26(1), 17-44.

Troia, G. A., Shankland, R. K., \& Wolbers, K. A. (2012). Motivation research in writing: Theoretical and empirical considerations. Reading \& Writing Quarterly, 28(1), 5-28.

Tschannen-Moran, M., \& McMaster, P. (2009). Sources of self-efficacy: Four professional development formats and their relationship to self-efficacy and implementation of a new teaching strategy. The elementary school journal, 110(2), 228-245.

Xu, X., Aron, A., Brown, L., Cao, G., Feng, T., \& Weng, X. (2011). Reward and motivation systems: A brain mapping study of early-stage intense romantic love in Chinese participants. Human brain mapping, 32(2), 249-257.

Zimmerman, B. J., Bonner, S., \& Kovach, R. (1996). Developing self-regulated learners: Beyond achievement to self-efficacy. American Psychological Association. 